\title{
Schwann Cell Migration Induced by Earthworm Extract via Activation of PAs and MMP2/9 Mediated through ERK1/2 and p38
}

\author{
Yung-Ming Chang, ${ }^{1,2}$ Ying-Ting Shih, ${ }^{1}$ Yueh-Sheng Chen, ${ }^{1}$ Chien-Liang Liu, ${ }^{3}$ \\ Wen-Kuei Fang, ${ }^{4}$ Chang-Hai Tsai, ${ }^{5}$ Fuu-Jen Tsai, ${ }^{1,6}$ Wei-Wen Kuo, ${ }^{7}$ Tung-Yuan Lai, ${ }^{8}$ \\ and Chih-Yang Huang 1 ,, 10
}

\author{
${ }^{1}$ Graduate Institute of Chinese Medical Science, China Medical University, Taiwan \\ ${ }^{2}$ School of Chinese Medicine, China Medical University, Taiwan \\ ${ }^{3}$ Emergency Department, China Medical University Hospital, Taiwan \\ ${ }^{4}$ Department of Neurosurgery, Chia-Yi Christian Hospital, Chia-Yi, Taiwan \\ ${ }^{5}$ Department of Healthcare Administration, Asia University, Taiwan \\ ${ }^{6}$ Department of Pediatrics, Medical Research and Medical Genetics, China Medical University, Taiwan \\ ${ }^{7}$ Department of Biological Science and Technology, China Medical University, Taiwan \\ ${ }^{8}$ School of Post-Baccalaureate Chinese Medicine, China Medical University, Taiwan \\ ${ }^{9}$ Graduate Institute of Basic Medical Science, China Medical University, Taichung 404, Taiwan \\ ${ }^{10}$ Department of Health and Nutrition Biotechnology, Asia University, Taichung, Taiwan
}

Correspondence should be addressed to Chih-Yang Huang, cyhuang@mail.cmu.edu.tw

Received 10 February 2009; Accepted 6 August 2009

Copyright ( $\odot 2011$ Yung-Ming Chang et al. This is an open access article distributed under the Creative Commons Attribution License, which permits unrestricted use, distribution, and reproduction in any medium, provided the original work is properly cited.

The earthworm, which has stasis removal and wound-healing functions, is a widely used Chinese herbal medicine in China. Schwann cell migration is critical for the regeneration of injured nerves. Schwann cells provide an essentially supportive activity for neuron regeneration. However, the molecular migration mechanisms induced by earthworms in Schwann cells remain unclear. Here, we investigate the roles of MAPK (ERK1/2, JNK and p38) pathways for earthworm-induced matrix-degrading proteolytic enzyme (PAs and MMP2/9) production in Schwann cells. Moreover, earthworm induced phosphorylation of ERK1/2 and p38, but not JNK, activate the downstream signaling expression of PAs and MMPs in a time-dependent manner. Earthworm-stimulated ERK1/2 and p38 phosphorylation was attenuated by pretreatment with U0126 and SB203580, resulting in migration and uPArelated signal pathway inhibition. The results were confirmed using small interfering ERK1/2 and p38 RNA. These results demonstrated that earthworms can stimulate Schwann cell migration and up-regulate PAs and MMP2/9 expression mediated through the MAPK pathways, ERK1/2 and p38. Taken together, our data suggests the MAPKs (ERK1/2, p38)-, PAs (uPA, tPA)-, MMP (MMP2, MMP9) signaling pathway of Schwann cells regulated by earthworms might play a major role in Schwann cell migration and nerve regeneration.

\section{Introduction}

Nerve regeneration is a complex physiological response that takes place after injury. Neurons can be separated into central and peripheral nervous systems, which have different anatomical structures and regeneration ability. In mammals, the central neurons without a myelin sheath are very difficult to regenerate. In contrast, the peripheral nervous system (PNS) with a myelin sheath exhibits easier regrowth [1]. The regrowth ability results from the intrinsic neuronal activities and surrounding non-neuronal properties in which Schwann cells provide an essentially supportive activity for neuron regeneration. Schwann cells differentiate into the myelin sheath of the PNS and can proliferate and migrate into the distal end in the injured nerve area to support axonal regrowth [2]. It has also been reported that Schwann cell migration, which also occurs at the proximal end of the injury area, provides a guide for regenerating axons by interacting with nerve fibers or basal lamina [3]. Schwann cell migration is crucial for successful axonal elongation 
$[3,4]$. Moreover, peripheral nerve injury locally activates Schwann cells and macrophages to synthesize a cocktail of neurotrophic factors, adhesion molecules, cytokines and growth-promoting surface molecules $[5,6]$. However, the factors that regulate Schwann cell migration and their signaling mechanisms remain unclear.

The mitogen-activated protein kinase (MAPK) family is a crucial regulator of the pathways involved in cell proliferation [7] and migration [8]. Extracellular signalregulated protein kinase (ERK) is the most extensively studied MAPK [9]. Recently, several studies found that after nerve injury, which increased ERK [10] phosphorylation, requires ERK to promote neurite outgrowth [11]. However, ERK has also been implicated in the migration of various cell types, including fibroblasts and carcinoma cells $[12,13]$, but not in Schwann cells. Interestingly, to promote migration, growth cones secrete proteases that are thought to dissolve cell-cell and cell-matrix adhesions during peripheral nerve regeneration. These proteases include the plasminogen activators (PAs), tissue PA (tPA) and urokinase PA (uPA) and their substrate, plasminogen [14]. Plasmin, activated by tPA or UPA, can activate MMP-9 and MMP-2 [15]. Many experiments have determined that after injury PA expression is rapidly induced in neurons $[14,16]$. A lack of plasminogen activators affects MMP-9 and MMP2 activity [17]. However, little is known about Schwann cell migration using MEK/ERK signaling pathways to active PAs and MMPs. In addition, c-Jun NH2-terminal kinase (JNK) and p38 are other members of the MAPK super family. Accumulating evidence has also implicated the JNK and p38 pathway in cell migration regulation [18]. The expression of matrix-degrading proteolytic enzymes (PAs and MMPs) could be regulated by JNK [19] and p38 [20] signal transduction pathways to promote migration in cells. Collectively, we investigated the important role of MAPKs in the regulation of PAs and MMPs activity in response to earthworm stimuli. Therefore, enhancing the migration ability of Schwann cells might be another potential approach to neuron regeneration.

With a history of several thousand years, the pharmacology and clinical application of traditional Chinese medicine has been well documented. Recently, biomedical material science combined with Chinese herbal medicine has been applied to nerve regeneration studies. For example, Schwann cells filled into a silicon rubber chamber can bridge a $15-\mathrm{mm}$ gap in rat sciatic nerves. Several Chinese medicines have been identified as enhancing neuron regeneration [21]. Therefore, neuron regrowth induction using Schwann cells and herbal medicine has good potential for treating injured nerves. The earthworm is a widely used Chinese herbal medicine [22]. It has dense nutritional content because of their soilbased origin [23]. Extracting medicinal compounds from the earthworm has traditionally been practiced by indigenous people throughout the world, more particularly in Asia [24]. Previous earthworm studies have shown its antimicrobial [25], hepatoprotective [23], anticancer [26] and scar woundhealing characteristics [27]. The anti-inflammatory activity together with antioxidant properties seems to be due to the high polyphenolic content in earthworm tissue [28].
Moreover, crude earthworm extract has a thrombolytic effect that could significantly promote blood circulation to remove stasis [29]. Lumbrokinase extracted from the earthworm has been used to treat stroke and cardiovascular diseases [30]. Lumbrokinase is a group of proteolytic enzymes [31] that include a plasminogen activator and plasmin [32]. It can dissolve fibrin directly and also activate plasminogen [33]. In healthy human volunteers, oral-administered earthworm powder increased levels of tPA and fibrinolytic activity [34]. Earthworm tissue homogenates have revealed a glycolipoprotein mixture referred to as G-90, composed of macromolecules. G-90 possesses several growth factors and also participates in tissue regeneration and wound healing [35]. In vivo experiments have also found that a mixed prescription of liquid extracted from earthworm more obviously improves peripheral nerve regeneration than icariin [36]. Verified earthworm nerve regenerating and movement enhancing effects on Schwann cells are unknown. There is as yet no conclusive explanation for the possible molecular mechanism involved in Schwann cell migrating effects. Therefore, this study investigates the molecular mechanism and signaling pathways of earthworm extract in neuron regeneration. Our results indicate that earthworm extract promotes Schwann cell migration through the activation of PAs and MMPs, namely ERK1/2 and p38MAPK pathways.

\section{Methods}

2.1. Earthworm Extraction. Spray-dried earthworm powder, Pheretima aspergillum (Annelida, Oligochaeta, Lumbricidae), was purchased from Wann-Guo Pharmaceutical Co., Ltd., Tainan, Taiwan, R.O.C. Two grams of earthworm powder was dissolved in $10 \mathrm{ml}$ of $70 \%$ ethanol and left at room temperature for $24 \mathrm{~h}$. The next day the clear supernatant fraction was collected after centrifugation at $2000 \mathrm{rpm}$ for $20 \mathrm{~min}$. The solvents were then removed using a water bath at $37^{\circ} \mathrm{C}$ for $4 \mathrm{~h}$. The extract was then centrifuged for $5 \mathrm{~min}$ at $5000 \mathrm{rpm}$ at $4^{\circ} \mathrm{C}$. The supernatant was then filtered through a $0.22 \mu \mathrm{m}$ microspin filter just prior to the experiments. The concentrations used in the in vitro model were $0,31.25,62.5$, $125,250,500$ and $1000 \mu \mathrm{g} / \mathrm{ml}$ for RSC96 cell treatment. All solutions were stored at $-80^{\circ} \mathrm{C}$.

2.2. Cell Culture and Treatments. RSC96 cells were purchased from American Type Culture Collection (ATCC) and cultured in Dulbecco's modified Eagle's medium (DMEM) supplemented with $10 \%$ fetal bovine serum (FBS), $4 \mathrm{mM}$ L-glutamate, $1.5 \mathrm{~g} / \mathrm{l}$ sodium bicarbonate and $1 \%$ nonessential amino acids (NEAAs) in a humidified atmosphere of 5\% $\mathrm{CO}_{2}$ and $95 \%$ air. RSC96 cells cultures were treated at the indicated times or concentrations with earthworm extract.

2.3. Inhibitor. RSC96 cells were treated with several inhibi-tors, including U0126 (MEK1 and MEK2 inhibitor; Promega) and SB203580 (p38 MAP kinase inhibitor; Promega). 
2.4. MTT. Cell viability was estimated using a colorimetric assay based on tetrazolium dye (MTT) conversion into a blue formazan product. All procedures were described in our previous study [37]. After harvesting and washing twice with PBS, the cells were cultured in phenol red-free DMEM ( $1 \mathrm{ml})$ with $\operatorname{MTT}(0.5 \mathrm{mg} / \mathrm{ml})$ at $37^{\circ} \mathrm{C}$ for $4 \mathrm{~h}$. The cells were then incubated in iso-propenol $(1 \mathrm{ml})$ with shaking for $10 \mathrm{~min}$, aspirated and measured spectrophotometerically at $570 \mathrm{~nm}$.

2.5. Migration. We used a Boyden chamber and polyvinylpyrrolidone-free polycarbonate membranes with $8-\mu \mathrm{m}$ pores (Neuro Probes, Inc.) for the migration assay. The bottom wells of the chamber were filled with 10\% FBS DMEM medium. The wells were covered with a membrane sheet, in which serum-free medium was added into the top chamber. Membranes were then stained with Giemsa stain (Sigma). Cells that migrated through the membrane were counted using a counting grid fitted into a phase contrast microscope eyepiece.

2.6. Wound Healing. Cells were initially seeded uniformly in 60-mm culture plates with an artificial "wound" carefully created at $0 \mathrm{~h}$, using a sterile $\mathrm{P}-200$ pipette tip to scratch the subconfluent cell monolayer to make an approximately $1.0-\mathrm{mm}$ gap. After $24 \mathrm{~h}$ of culture with $125 \mu \mathrm{g} / \mathrm{ml}$ earthworm concentration, the cell migration was calculated by counting cell numbers that had advanced into the cell-free space randomly selected from an area at the initial wound border. Photographs were taken of the wounded regions using an inverted Olympus microscope.

2.7. Western Blot. Cultured RSC96 cells were scraped and washed once with PBS. The cell suspension was then spun down and cell pellets were lysed for $30 \mathrm{~min}$ in lysis buffer [50 mM Tris (pH 7.5), 0.5 M NaCl, 1.0 mM EDTA (pH 7.5), $10 \%$ glycerol, $1 \mathrm{mM}$ BME, 1\% IGEPAL-630 and proteinase inhibitor cocktail (Roche)] and centrifuged at $12000 \mathrm{~g}$ for $10 \mathrm{~min}$. The supernatants were removed and placed in new Eppendorf tubes for western blot analysis. Proteins from the RSC96 cells were separated in 12\% gradient SDSPAGE and transferred onto nitrocellulose membranes. Nonspecific protein binding was blocked in blocking buffer at RT for $1 \mathrm{~h}$ (5\% milk, $20 \mathrm{mM}$ Tris- $\mathrm{HCl}$, pH $7.6150 \mathrm{mM} \mathrm{NaCl}$ and $0.1 \%$ Tween 20). The membranes were blotted with specific antibodies and incubated in $4^{\circ} \mathrm{C}$ blocking buffer overnight. For repeated blotting, nitrocellulose membranes were stripped with Restore Western blot stripping buffer (Pierce Biotechnology, Inc, Rockford, IL, USA) at room temperature for $30 \mathrm{~min}$. Densitometric analysis of immunoblots was performed using the AlphaImager 2200 digital imaging system (Digital Imaging System, CA, USA). Experiments were performed in triplicate.

2.8. Zymography. MMP-2 and MMP-9 activity was determined using gelatin zymography. RSC96 cells were treated with earthworm extract at different times. After incubation for $0,4,8,12,16,20$ and $24 \mathrm{~h}$, the cell medium was collected. Sample medium was electrophoresed on an $8 \%$ polyacrylamide gel containing $0.1 \%$ gelatin. After electrophoresis, the gel was washed for $30 \mathrm{~min}$ two times in washing buffer $(2.5 \%$ Triton $\mathrm{X}-100)$. The gel was then incubated in incubation buffer $\left(1 \% \mathrm{NaN}_{3} ; 2 \mathrm{M}\right.$ Tris-HCl, $\left.\mathrm{pH} 8.0 ; 1 \mathrm{M} \mathrm{CaCl}_{2}\right)$ at $37^{\circ} \mathrm{C}$ for $24 \mathrm{~h}$ with shaking and subsequently stained with Coomassie blue. The presence of MMP-2 and MMP-9 gelatinolytic activity was identified as clear bands on a blue background after destaining.

2.9. siRNA. Double-stranded siRNA sequences targeting MEK and p38 mRNAs were obtained from Dharmacon. A non-specific duplex (Dharmacon) was used as a control. RSC96 cells were cultured in 100-mm well plates in DMEM without FBS and transfected with double-stranded siRNA using the DharmaFECT Duo Transfection Reagent (Dharmacon) according to the manufacturer's instructions. To assess gene silencing, the ERK1/2 ans p38 protein level was detected by western blot.

2.10. Statistical Analysis. Statistical differences were assessed using one-way ANOVA. $P<.05$ was considered statistically significant. Data were expressed as the mean \pm SEM.

\section{Results}

3.1. Effects of Earthworm on Cell Viability. We evaluated the proliferative effect of earthworm extract on the regenerative ability of RSC96 cells. During experiments, we first observed the effect of various earthworm extract concentrations $(0$, $31.25,62.5,125,250,500$ and $1000 \mu \mathrm{g} / \mathrm{ml}$ ) on cell viability for $24 \mathrm{~h}$. We found that cellular viability was significantly elevated with the concentration at $125 \mu \mathrm{g} / \mathrm{ml}$ for $24 \mathrm{~h}$ (Figure 1). However, some of the effects were reversed back to the basal level at doses of $250-1000 \mu \mathrm{g} / \mathrm{ml}$, indicating that the toxicity effect of earthworm extract could occur at high concentrations. These results may elucidate that treatment with $125 \mu \mathrm{g} / \mathrm{ml}$ earthworm extract appears to induce cell proliferation. Moreover, the viability of ethanoltreated Schwann cells was not affected (data not shown).

3.2. Earthworm Promotes the Migration of RSC Cell. The property of RSC96 cells to migrate along the growth direction, leading to regenerating damaged nerves is important in helping the damaged peripheral nerve regeneration [38]. Therefore, we further performed an in vitro woundhealing experiment to evaluate the migration potential of RSC96 cells. As shown in Figure 2(a), treatment with $125 \mu \mathrm{g} / \mathrm{ml}$ earthworm extract for $24 \mathrm{~h}$ significantly enhanced the mobility of RSC96 cells. Moreover, the same treatment also strongly promoted cell migration in either water- or ethanol-treated controls in Boyden chambers. These samples were stained and counted (Figure 2(b)). These observations provide evidence of earthworm extract-induced RSC96 cell proliferation and migration to enhance nerve regeneration.

3.3. Role of MAPKs in Earthworm Induced RSC Cell Migration. We further examined the Schwann cell migration mechanisms using earthworm extract. As shown in Figure 3(c), the protein levels were measured using western 


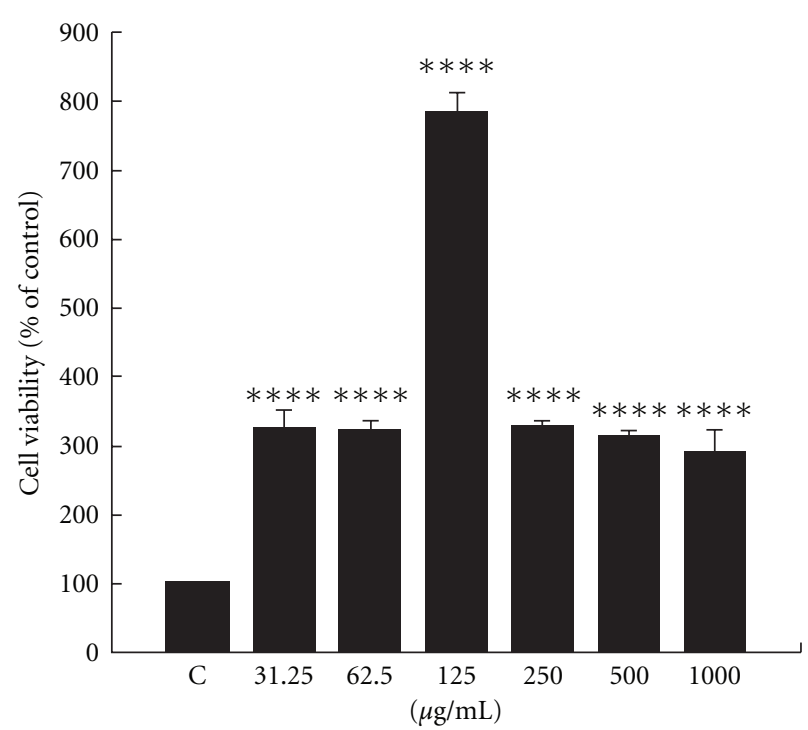

FIGURE 1: Effect of earthworm extract on RSC96 cell viability. Schwann cells were treated with $0-1000 \mu \mathrm{g} / \mathrm{ml}$ earthworm extract for $24 \mathrm{~h}$. Cell viability, measured by MTT assay, was described under materials and methods section. Data are shown as the mean of three independent experiments \pm SE. ${ }^{* * * *}$ denote significant differences from control values with $P<.0001$.

blotting. The MAPK signal pathway activation mechanism results for RSC96 cells treated with earthworm extract show a time course effect. In contrast to ERK1/2 and p38, JNK phosphorylation began to decline in the same time period as ERK and p38 activity increased. We suggest that earthworm extract could induce the phosphorylation of ERK1/2 and the p38 signal pathway to promote migration in Schwann cells. Moreover, uPA and tPA proteins also rapidly increase and conversely the PAI-1 protein level gradually decreases. Interestingly, the maximal tPA expression was observed early at $4 \mathrm{~h}$ in Schwann cells treated with earthworm extract. RSC96 cells exposed to earthworm extract also induced the expression of MMP9 and MMP2 proteins, their activity (Figure 3(d)), and decreased TIMP1 and TIMP2 levels. These results indicate that earthworm extract might be mediated through the activation of ERK1/2 and p38 pathways to induce PAs and MMP2/9, resulting in Schwann cell migration.

3.4. RSC Cell Migration Enhanced by Earthworm Is ERK1/2 and p38 Signalingdependent In Vitro. It has been demonstrated that earthworm extract can significantly activate ERK1/2 and p38. We then examined whether earthworminduced cell migration indeed occurred through ERK1/2 and p38 MAPK. We used specific MAPK cascade inhibitors: U0126, and SB203580. Schwann cells were pretreated with U0126 and SB203580 pharmacological inhibitors, followed by incubation with earthworm extract at $125 \mu \mathrm{g} / \mathrm{ml}$ concentration for $24 \mathrm{~h}$. Our data reveal that ERK1/2 and p38 inhibition activity significantly blocked earthworm-increased cell migration (Figures $4(\mathrm{a})-4(\mathrm{c})$ and Figures $4(\mathrm{e})-4(\mathrm{~g}))$. The downstream substrate of ERK1/2 and p38 in the signaling activated by earthworm extract was blocked (Figures $4(\mathrm{~d})$ and $4(\mathrm{~h}))$. To further confirm the role of ERK and p38 in earthworm extract enhanced cell migration, we chose to deplete ERK and p38 using siRNA (Figure 5). Most importantly, reduced ERK expression with siRNA also markedly attenuated earthworm-induced migration compared with the control. Similarly, p38 siRNA at the same concentration did reduce cell migration. Western blots showed that there was a significant reduction in the pERK and p-p38 protein level in Schwann cells transfected with MEK or p38 siRNA. Consistent with the inhibitor effect, cell migration induced by earthworm extract was clearly reduced in the presence of ERK1/2 and p38 MAPK siRNA. Therefore, our results demonstrate that earthworm extract-induced Schwann cell migration occurs by activating the PAs and MMPs dependent on the ERK1/2 and p38 MAPK pathways.

\section{Discussion}

The overall aim of this study was to investigate the mechanism in which earthworm extract regulates Schwann cell migration. We demonstrated a specific signaling migration pathway in earthworm-stimulated Schwann cells, inducing the activation of uPA and tPA mediated through the ERK1/2 and p38 (Figure 6). When cells-treated earthworm extract resulted in ERK1/2 and p38 phosphorylation, the expression of uPA and tPA occurred in a time-dependent manner, leading to elevated MMP9 and MMP2 levels and activity. Using inhibitors and siRNA, the migrative effects of earthworm extract on Schwann cells were further identified to beERK1/2 and p38 signaling dependent.

Chinese herbal medicines have attracted a great deal of attention as alternative and supplemental medicines [39]. For thousands of years the earthworm has been used as a drug for various diseases in China and the Far East [34]. Schwann cells in the injured nerve area migrate and form a Büngner band, supporting axonal regrowth [2]. The function of earthworm extract on nerve regeneration is unknown and migratory Schwann cell mechanism with earthworm extract treatment is totally obscure. Recently studies have demonstrated that MAPKs, including JNK, p38 and ERK1/2, play crucial roles in nerve cell migration [40]. This further demonstrated that earthworm extract stimulated ERK1/2 and p38, but not JNK activation in a time-dependent manner, leading to Schwann cell migration. Earthworm-induced Schwann cell motility and phosphorylation of ERK1/2 and p38 were both attenuated by pretreatment with MEK1/2 (U0126) and p38 (SB203580) inhibitors. Transfection with siRNA of MEK1/2 and p38 significantly reduced migration in response to earthworm extract in Schwann cells as well. These assays, allow us to examine the individual steps in the complex signaling cascades and clearly illustrate direct earthworm extract effects on Schwann cell migration.

It has been reported that the highly expressed uPA in the epidermis of damaged tissue is regulated by the fibroblast growth factor (FGF-2) which affects MAPK kinase (MEKK1) and MEKK-1's downstream ERK1/2 for controlling uPA expression [41]. The p38 MAPK pathway also participates in endothelial cell migration by regulating uPA expression [42]. 


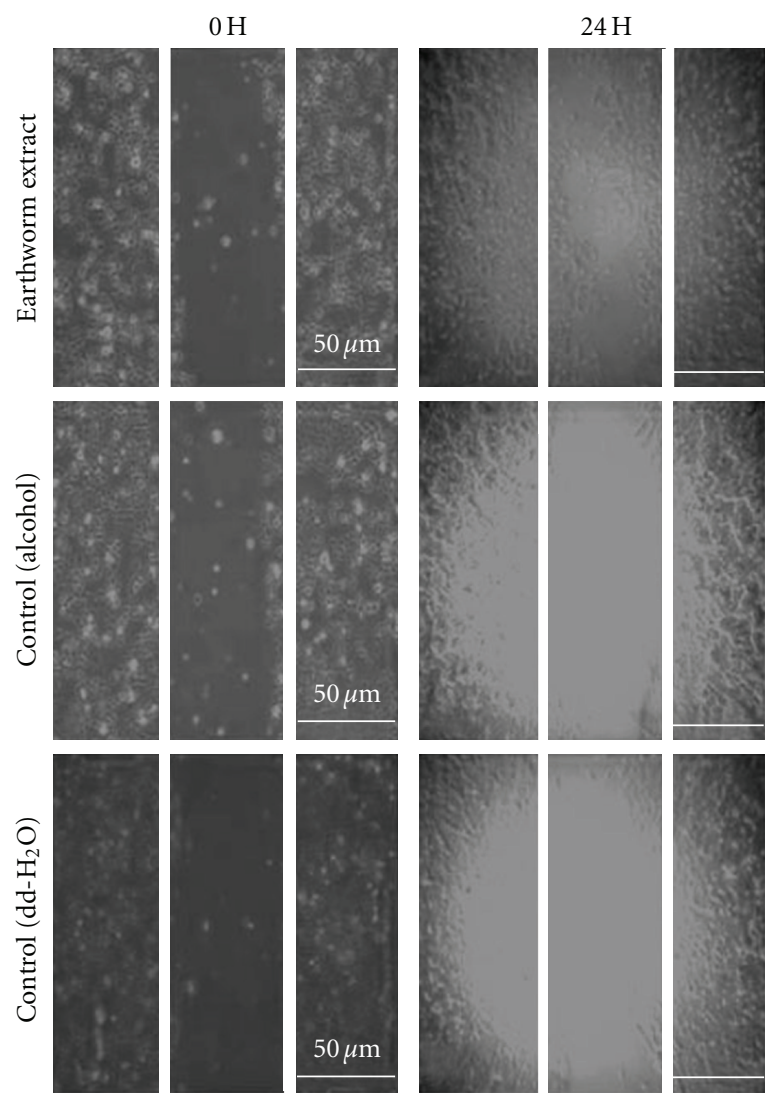

(a)


(b)

FIGURE 2: The migrative effect of earthworm extract on RSC96 cell. Schwann cells were treated with $125 \mu \mathrm{g} / \mathrm{ml}$ earthworm extract for $24 \mathrm{~h}$ as indicated, and cell migration as measured by wound healing analysis (a) and Boyden chambers (b) were described under materials and methods. Data are shown as the mean of three independent experiments \pm SE. ${ }^{* * *}$ denote significant differences from control values with $P<.001$.

We further identified that earthworm extract enhances uPA expression directly through the ERK $1 / 2$ and p38 signaling pathway. To promote migration, cells secrete proteases that are thought to degrade matrix molecules and cell adhesion. These proteases include tPA and Upa [14]. In contrast to PAs, PAI-1 is thought to be the major inhibitor. Our data clearly shows that the phosphorylation of ERK1/2 and p38 accompanies the increased expression of uPA. Conversely, PAI-1 expression is gradually decreased. Interestingly, tPA levels reached the maximal early at $2 \mathrm{~h}$ and then started to slightly decline until $20 \mathrm{~h}$. We suggest that the maximum expression of tPA occurred early following 4-h treatment, because tPA is the main PAs in the nerve growth cones [43]. tPA is consequently rapidly induced by earthworm extract. Pittman and Dibenedetto reported that overexpressing tPA regenerates neurites to a greater extent and migrates faster than control cells in complex extracellular matrix [44]. Ulfhammer et al. found that tPA activation could be mediated through p38 pathways, leading to an increase in tPA expression [45]. Our experiments further show that SB203580 inhibited p38 phosphorylation and suppressed tPA protein expression in Schwann cells. Thus,
tPA activation occurs not only through ERK1/2 activation, but also through the p38 signaling pathway.

The development and regeneration of the PNS is highly dependent on the migration of Schwann cells and the extension of axons toward their distant targets. PAs are associated with several neural cell types where they are believed to mediate localized degradation of the extracellular matrix (ECM), thus facilitating cell motility [46]. Degradation of the ECM is associated with the development of tumor metastasis and neuron tissue growth. One of the key regulators of this process is the serine protease, uPA, acting on a wide variety of ECM components [47]. The cell proliferation [48] and angiogenesis [49] processes are events involving uPA catalytic ECM degradation. Interestingly, several studies have reported that Schwann cells also produce some growth factors, which are crucial for peripheral nerve repair, such as FGF-2. FGF-2 is one of the mediators of uPA activity, and induces signals to control uPA expression and function [41]. We suggest that ERK1/2 and $\mathrm{p} 38$ phosphorylation could promote uPA expression in earthworm extract-treated cells, which could be mediated through the modulation of FGF2. Another family of proteases, the matrix metalloproteases 


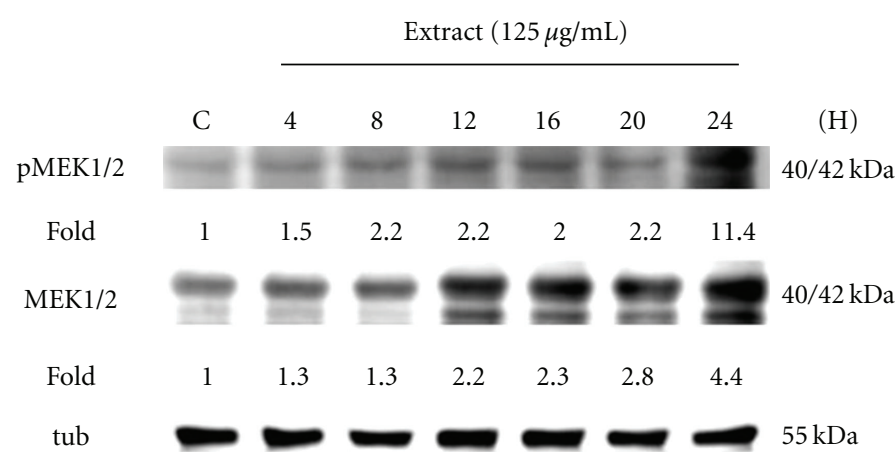

(a)

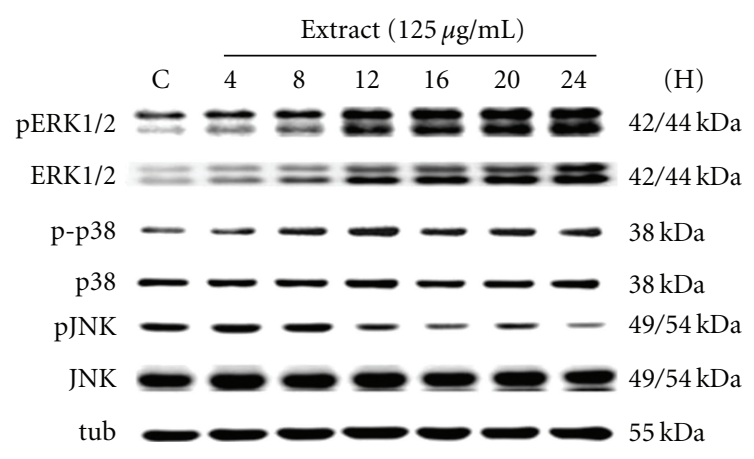

(b)

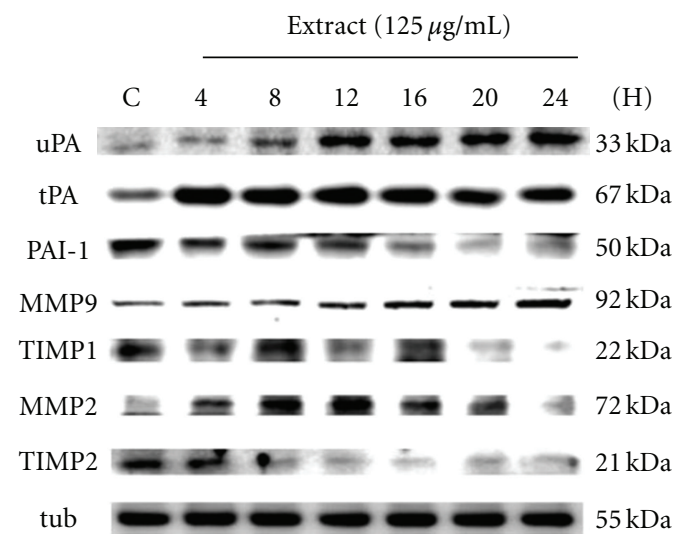

(c)

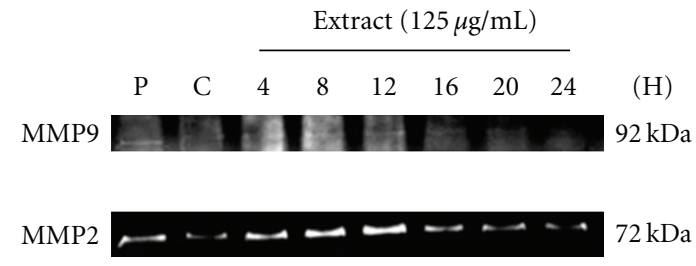

(d)

FIGURE 3: MAPK signal pathway activation time course for Schwann cells treated with earthworm extract. Schwann cells were treated with $125 \mu \mathrm{g} / \mathrm{ml}$ earthworm for different time as indicated, and then the cells were harvested and extracted for the western blot analysis. The protein expression of the MAPK signal pathway was determined by western blot (a)-(c). $\alpha$-Tubulin was used as a loading control. Further to confirm the MMP-9 and MMP2 activity by gelatin zymography (d). Lane 1: FBS as positive marker (P).

(MMPs), are also implicated in peripheral nerve regeneration [50], and involved in many cell migration phenomena and produced by many cell types, including neurons [51]. MMPs are secreted as inactive molecules and require activation via other proteases [52]. Plasmin, activated by tPA or uPA, can activate MMP-9 and MMP-2 [15]. Our results also show the elevated protein expression and activity of MMP2 and MMP9.

Earthworm extract is commonly used in Chinese medicine. It has a dense nutritional content because of its soil-based origin [23]. Lumbrokinase (LK) is a group of six novel proteolytic enzymes derived from the earthworm Lumbricus rubellas [53], as a strong fibrinolytic enzyme [54]. Recent studies have shown that the fibrinolytic enzymes could dissolve blood fibrin clots and inhibit platelet activation and aggregation [55]. Its therapeutic and preventive effects for thrombosis-related disease have been clinically confirmed [56]. A novel fibrinolytic enzyme also found from Pheretima aspergillum can dissolve human thrombi and fibrin directly and strongly, and also activate human plasminogen to plasmin. This enzyme showed little toxic side effects in animal tests [33]. Several experiments have indicated that earthworm fibrinolytic enzyme acts as a plasminogen activator [57], suggesting a tPA-like function
[58]. A biologically active glycolipoprotein extract from a whole earthworm tissue homogenate was isolated and named G-90 [59]. It is neither mutagenic nor cancerogenic [60]. It was recently shown that G-90 is neither allergic nor toxic, and possesses antibacterial activity [61] and antioxidative effects [62]. G-90 exhibits many biological functions important in the proliferation [63] and adhesion [64] of cells. The G-90 mixture contains insulin like growth factors, immunoglobulin-like growth factor, serine proteases and epidermal growth factor (EGF) $[6,35,59,61,63,64]$. Furthermore, it also contains molecules to activate signal transduction pathways, which in vivo help the tissue regeneration process; that is, wound healing. In vivo experiments showed stimulation of EGF and FGF synthesis in skin wounds using G-90 [65]. In cell cultures, after treatment with $\mathrm{H}_{2} \mathrm{O}_{2}$ for $4 \mathrm{~h}, \mathrm{G}-90$ allows the cells to recover and stimulated their growth. G-90 could be a useful wound-healing agent [62]. The neural cell adhesion molecule (NCAM) is a member of the immunoglobulin superfamily. Several studies showed that NCAM-induced neurite outgrowth depends on Ras-mitogen-activated protein (MAP) kinase pathway activation [66]. NCAM-dependent cell migration to fibronectin required an intact MEK-ERK signaling pathway [67]. The adhesins of the immunoglobulin superfamily from 


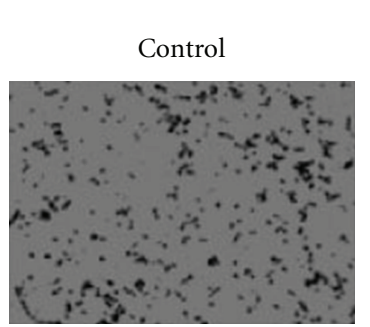

(a)

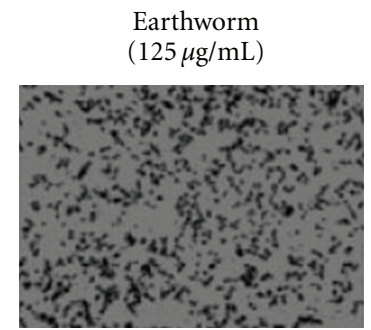

(b)

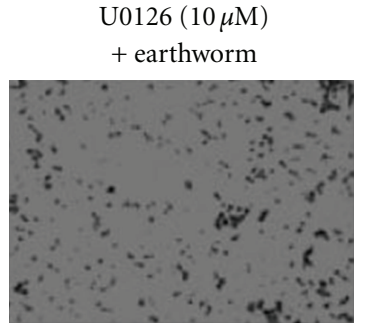

(c)

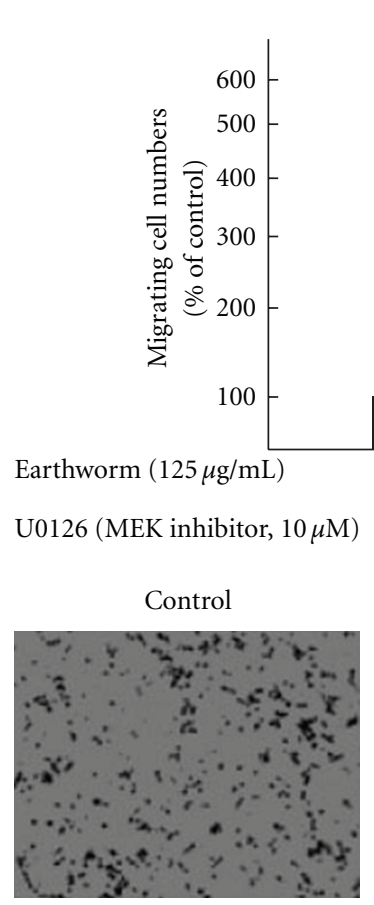

(e)

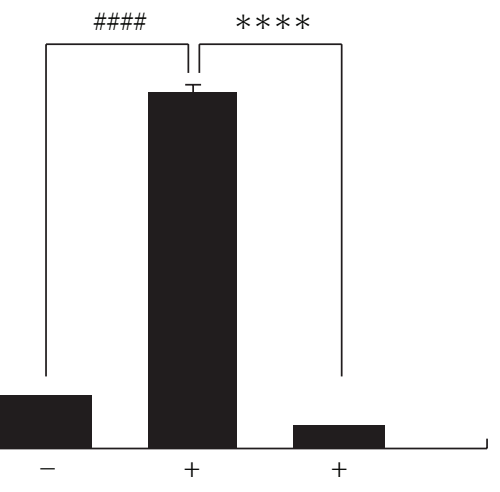

$+$

Earthworm $(125 \mu \mathrm{g} / \mathrm{mL})$

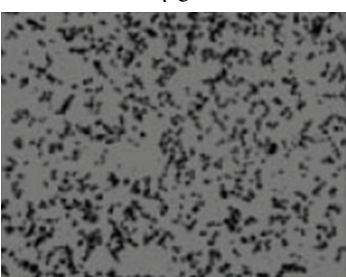

(f)

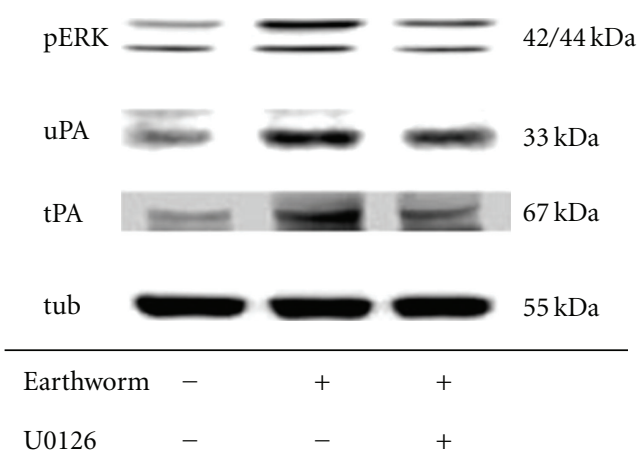

(d)

+ earthworm

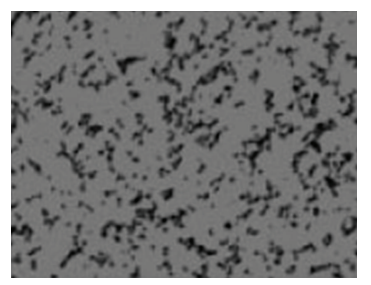

$(\mathrm{g})$

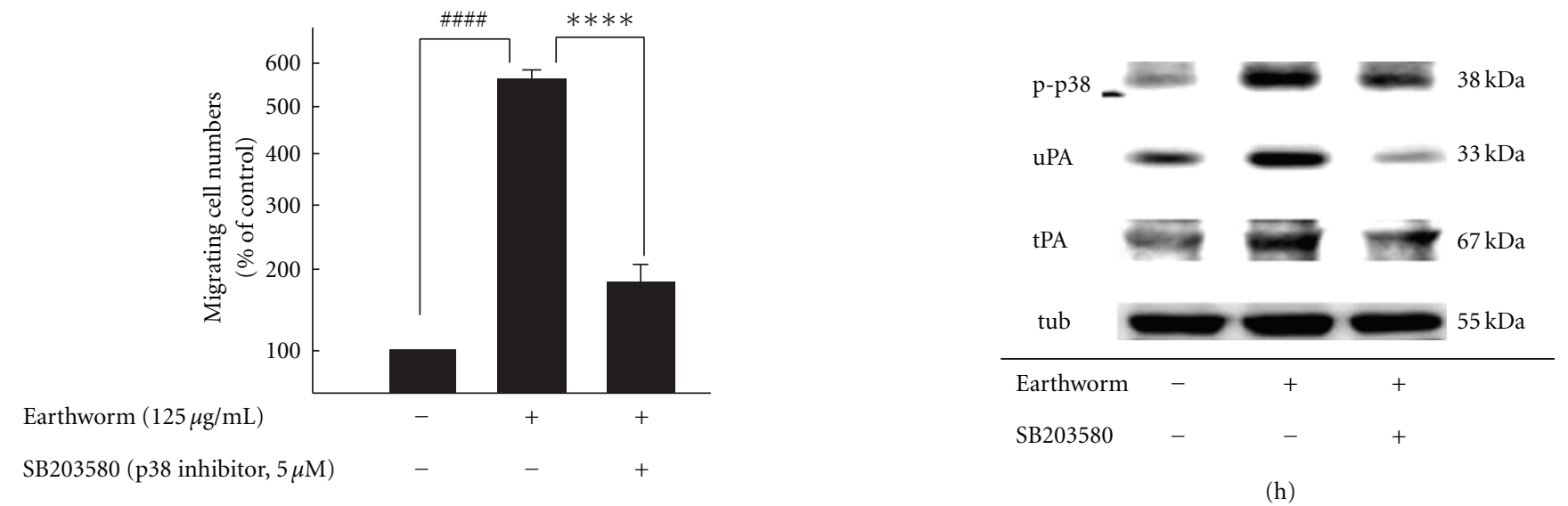

FIGURE 4: Earthworm extract effects on Schwann cell migration was ERK1/2 and p38 signaling dependent. RSC cells were pretreated with $\mathrm{U} 0126$ or SB203580 for $1 \mathrm{~h}$, then treated with $125 \mu \mathrm{g} / \mathrm{ml}$ earthworm extract for $24 \mathrm{~h}$. After incubation with earthworm extract, migration was assayed using Boyden chambers $((\mathrm{a})-(\mathrm{c}),(\mathrm{e})-(\mathrm{g}))$. Cells that migrated through the membrane were counted using a counting grid fitted into a phase contrast microscope eyepiece. The results shown are the mean number of migrating cells per field performed in triplicate. Western blot analysis of many protein levels, as indicated, in RSC cells treated with earthworm extract. ((d) and (h)). \#\#\#\# denote significant differences from control values with $P<.0001$. ${ }^{* * * *}$ denote significant differences treated with earthworm extract only values with $P<.0001$. 
Control

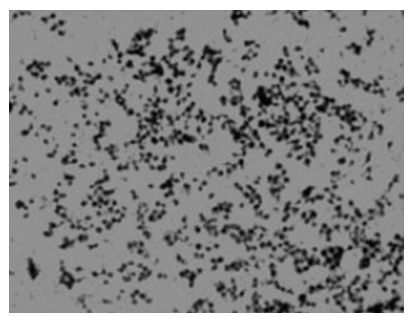

(a)
Earthworm $(125 \mu \mathrm{g} / \mathrm{mL})$

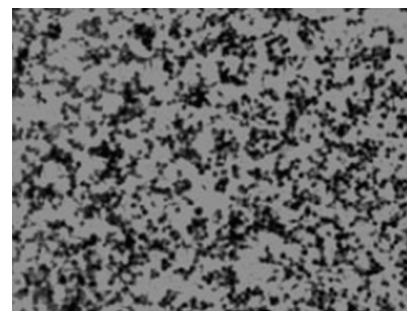

(b)

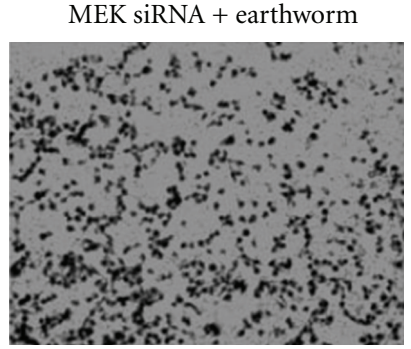

(c)

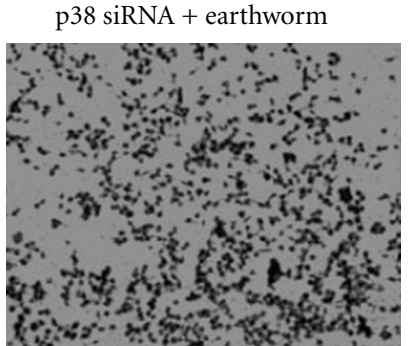

(d)

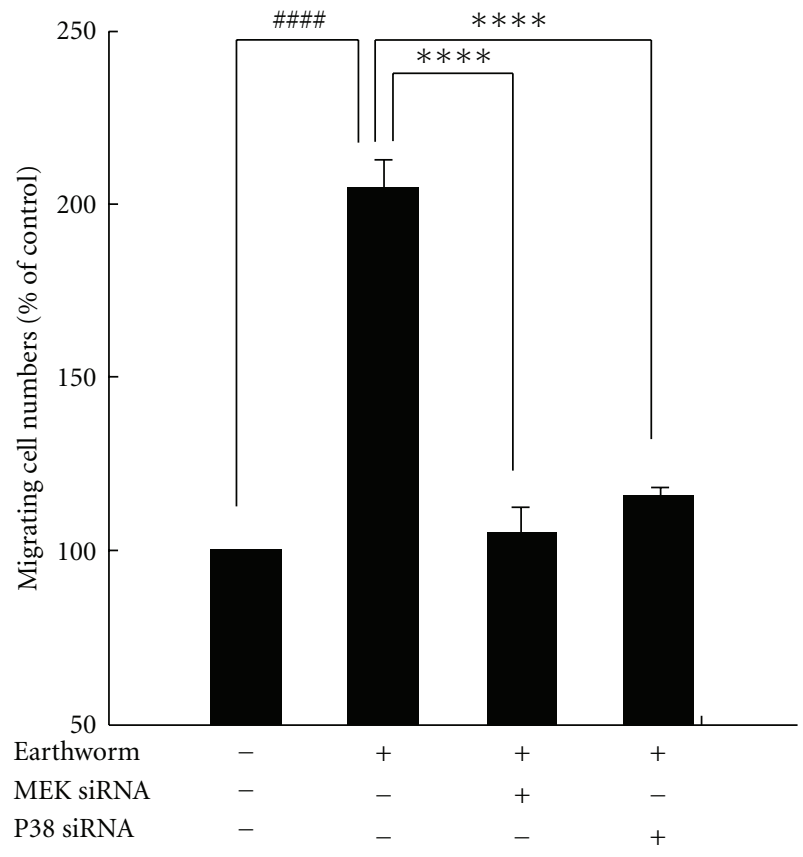

(e)

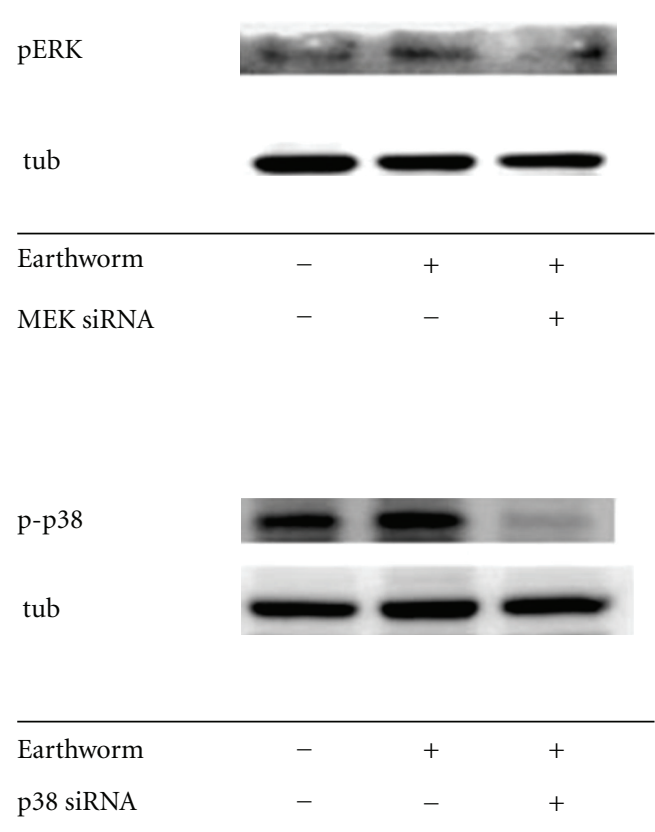

(f)

FIGURE 5: ERK1/2 and p38 signaling required for earthworm-induced cell migration. RSC cells were transiently transfected with ERK1/2 siRNA $(100 \mathrm{nM})$ or p38 MAPK siRNA $(100 \mathrm{nM})$ for $8 \mathrm{~h}$, then treated with $125 \mu \mathrm{g} / \mathrm{ml}$ earthworm extract for $24 \mathrm{~h}$. After incubation with earthworm extract, migration was assayed using Boyden chambers $((\mathrm{a})-(\mathrm{d}))$. Cells that migrated through the membrane were counted using a counting grid fitted into a phase contrast microscope eyepiece. The results shown are the mean number of migrating cells per field performed in triplicate (e). After treatment with earthworm extract for $24 \mathrm{~h}$ to prepare protein lysates and following western blot assay using anti-pERK or p-p38 antibody (f). \#\#\# denote significant differences from untreated control values with $P<.0001$. **** denote significant differences from treated with earthworm extract only values with $P<.0001$.

earthworm extract could promote migration by MEK-ERK pathway activation. These bioactive compounds may indirectly cause ERK activation or directly activate plasminogen to plasmin by fibrinolytic enzyme, resulting in Schwann cell migration promotion in nerve regeneration. Based on these facts, we suggest that earthworm extract or some of its components could have cell migration promotion potential. Our results demonstrate that earthworm extract can stimulate Schwann cell migration and up regulate PAs and MMP2/9 expression mediated through the MAPK pathways, ERK1/2 and p38. Further analyses are needed to determine the presence of bioactive compounds that promote cell migration in earthworm extract.

The findings of our study provide another neuron regeneration novel function. However, the nerve growthsuppressing action by high doses of earthworm extract at concentrations of $250-1000 \mathrm{mg} / \mathrm{ml}$, indicates that an excessive earthworm extract load in the medium could provoke an adverse response to neuron regeneration recovery. The data agree with the results of Boyd and Gra's study [68], demonstrating that excessive supplement could saturate the neurotrophin receptor, p75, to block the neuron 


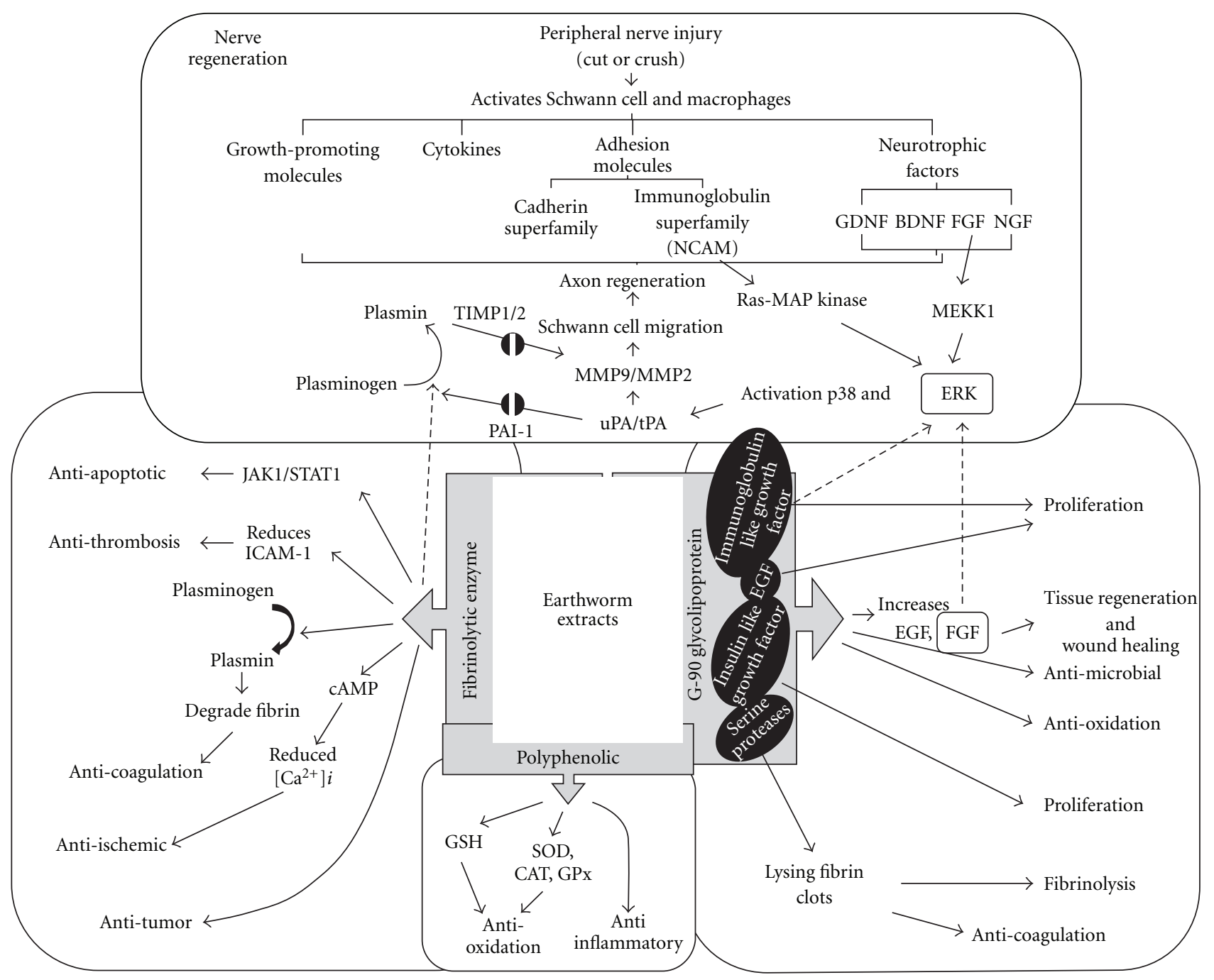

FIGURE 6: Schematic model of earthworm extract migrative effects on RSC96 Schwann cells. Stimulation of Schwann cells with earthworm activates ERK1/2 and p38 signaling, leading to upregulating uPA and tPA, and contributing to activating MMP9 and MMP2, enhancing the Schwann RSC96 cell migration. NCAM, neural cell adhesion molecule; GDNF, glial cell line-derived neurotrophic factor; BDNF, brain-derived neurotrophic factor; FGF, fibroblast growth factor; NGF, nerve growth factor; ICAM-1, intercellular adhesion molecule1; JAK1/STAT1, janus kinase1/signal transducers and activators of transcription1; GSH, glutathione; GPx, glutathione peroxidase; CAT, catalase; EGF, epidermal growth factor. Dotted lines indicate the hypothetical molecular mechanism of the bioactive compound present in earthworm powder.

regrowth promoting function. Excessive nerve growth factor administration could delay the neurotrophic factor, growthassociated protein 43 (GAP 43) induction and early phase peripheral nerve regrowth [69]. Therefore, an appropriate dose of earthworm extract should be carefully selected to reach the highest potential for enhanced Schwann cell migration. Earthworm extract might serve as a promising migration inducing and/or therapeutic drug for nerve regeneration.

\section{Funding}

China Medical University (CMU95-058, CMU95-060, CMU96-102 and CMU97-CMC-007).

\section{Acknowledgment}

W.-W. Kuo, T.-Y. Lai, and C.-Y. Huang contribute equally to this work.

\section{References}

[1] R. P. Bunge, "Expanding roles for the Schwann cell: ensheathment, myelination, trophism and regeneration," Current Opinion in Neurobiology, vol. 3, no. 5, pp. 805-809, 1993.

[2] J. W. Fawcett and R. J. Keynes, "Peripheral nerve regeneration," Annual Review of Neuroscience, vol. 13, pp. 43-60, 1990.

[3] K. Torigoe, H.-F. Tanaka, A. Takahashi, A. Awaya, and K. Hashimoto, "Basic behavior of migratory Schwann cells in peripheral nerve regeneration," Experimental Neurology, vol. 137, no. 2, pp. 301-308, 1996. 
[4] E. S. Anton, A. W. Sandrock Jr., and W. D. Matthew, "Merosin promotes neurite growth and Schwann cell migration in vitro and nerve regeneration in vivo: evidence using an antibody to merosin, ARM-1," Developmental Biology, vol. 164, no. 1, pp. 133-146, 1994.

[5] C. Ide, "Peripheral nerve regeneration," Neuroscience Research, vol. 25, no. 2, pp. 101-121, 1996.

[6] W. D. Snider, F.-Q. Zhou, J. Zhong, and A. Markus, "Signaling the pathway to regeneration," Neuron, vol. 35, no. 1, pp. 13-16, 2002.

[7] G. Pearson, F. Robinson, T. B. Gibson et al., "Mitogenactivated protein (MAP) kinase pathways: regulation and physiological functions," Endocrine Reviews, vol. 22, no. 2, pp. 153-183, 2001.

[8] S. Meintanis, D. Thomaidou, K. R. Jessen, R. Mirsky, and R. Matsas, "The neuron-glia signal $\beta$-neuregulin promotes Schwann cell motility via the MAPK pathway," GLIA, vol. 34, no. 1, pp. 39-51, 2001.

[9] P. P. Roux and J. Blenis, "ERK and p38 MAPK-activated protein kinases: a family of protein kinases with diverse biological functions," Microbiology and Molecular Biology Reviews, vol. 68, no. 2, pp. 320-344, 2004.

[10] W. Ma and R. Quirion, "The ERK/MAPK pathway, as a target for the treatment of neuropathic pain," Expert Opinion on Therapeutic Targets, vol. 9, no. 4, pp. 699-713, 2005.

[11] P. Wiklund, P. A. Ekstrom, and A. Edstrom, "Mitogenactivated protein kinase inhibition reveals differences in signalling pathways activated by neurotrophin-3 and other growth-stimulating conditions of adult mouse dorsal root ganglia neurons," Journal of Neuroscience Research, vol. 67, pp. 62-68, 2002.

[12] C. Huang, K. Jacobson, and M. D. Schaller, "MAP kinases and cell migration," Journal of Cell Science, vol. 117, no. 20, pp. 4619-4628, 2004.

[13] K. B. Reddy, S. M. Nabha, and N. Atanaskova, "Role of MAP kinase in tumor progression and invasion," Cancer and Metastasis Reviews, vol. 22, no. 4, pp. 395-403, 2003.

[14] L. B. Siconolfi and N. W. Seeds, "Mice lacking tPA, uPA, or plasminogen genes showed delayed functional recovery after sciatic nerve crush," Journal of Neuroscience, vol. 21, no. 12, pp. 4348-4355, 2001.

[15] G. Murphy, S. Atkinson, R. Ward, J. Gavrilovic, and J. J. Reynolds, "The role of plasminogen activators in the regulation of connective tissue metalloproteinases," Annals of the New York Academy of Sciences, vol. 667, pp. 1-12, 1992.

[16] L. B. Siconolfi and N. W. Seeds, "Induction of the plasminogen activator system accompanies peripheral nerve regeneration after sciatic nerve crush," Journal of Neuroscience, vol. 21, no. 12, pp. 4336-4347, 2001.

[17] L. B. Siconolfi and N. W. Seeds, "Mice lacking tissue plasminogen activator and urokinase plasminogen activator genes show attenuated matrix metalloproteases activity after sciatic nerve crush," Journal of Neuroscience Research, vol. 74, no. 3, pp. 430434, 2003.

[18] C. Huang, K. Jacobson, and M. D. Schaller, "MAP kinases and cell migration," Journal of Cell Science, vol. 117, no. 20, pp. 4619-4628, 2004.

[19] S. Koochekpour, O. Sartor, M. Hiraiwa et al., "Saposin C stimulates growth and invasion, activates p42/44 and SAPK/JNK signaling pathways of MAPK and upregulates UPA/uPAR expression in prostate cancer and stromal cells," Asian Journal of Andrology, vol. 7, no. 2, pp. 147-158, 2005.

[20] M. Hecht, U. Heider, M. Kaiser, I. von Metzler, J. Sterz, and O. Sezer, "Osteoblasts promote migration and invasion of myeloma cells through upregulation of matrix metalloproteinases, urokinase plasminogen activator, hepatocyte growth factor and activation of p38 MAPK," British Journal of Haematology, vol. 138, no. 4, pp. 446-458, 2007.

[21] C.-C. Tsai, M.-C. Lu, Y.-S. Chen, C.-H. Wu, and C.-C. Lin, "Locally administered nerve growth factor suppresses ginsenoside Rb 1-enhanced peripheral nerve regeneration," American Journal of Chinese Medicine, vol. 31, no. 5, pp. 665673, 2003.

[22] E. L. Cooper, "Bioprospecting: a CAM frontier," EvidenceBased Complementary and Alternative Medicine, vol. 2, no. 1, pp. 1-3, 2005.

[23] M. Balamurugan, K. Parthasarathi, L. S. Ranganathan, and E. L. Cooper, "Hypothetical mode of action of earthworm extract with hepatoprotective and antioxidant properties," Journal of Zhejiang University: Science B, vol. 9, no. 2, pp. 141-147, 2008.

[24] L. S. Ranganathan, "Vermibiotechnologyrom soil health to human health," Jodhpur, India, Agrobios, 2006.

[25] E. L. Cooper, "CAM, eCAM, bioprospecting: the 21st century pyramid," Evidence-Based Complementary and Alternative Medicine, vol. 2, no. 2, pp. 125-127, 2005.

[26] E. L. Cooper, B. Ru, and N. Weng, "Earthworms: sources of antimicrobial and anticancer molecules," Advances in Experimental Medicine and Biology, vol. 546, pp. 359-389, 2004.

[27] M. Zhang, X. Li, Y. Liu, F. Ye, and G. Qiu, "Effects of extract of Dilong (Pheretima) on the scalded skin in rats," Journal of Traditional Chinese Medicine, vol. 26, no. 1, pp. 68-71, 2006.

[28] E. L. Cooper, M. Balamurugan, K. Parthasarathi, and L. S. Ranganathan, "Earthworm paste (Lampito mauritii, Kinberg) alters inflammatory, oxidative, haematological and serum biochemical indices of inflamed rat," European Review for Medical and Pharmacological Sciences, vol. 11, no. 2, pp. 7790, 2007.

[29] Z. X. Zhang and F. F. Wang, "Effects of crude extract of earthworm on promoting blood circulation to removing stasis," Zhongguo Zhong Xi Yi Jie He Za Zhi, vol. 12, no. 12, pp. 741-710, 1992.

[30] L. Jin, H. Jin, G. Zhang, and G. Xu, "Changes in coagulation and tissue plasminogen activator after the treatment of cerebral infarction with lumbrokinase," Clinical Hemorheology and Microcirculation, vol. 23, no. 2-4, pp. 213-218, 2000.

[31] E. L. Cooper, "Complementary and alternative medicine, when rigorous, can be science," Evidence-Based Complementary and Alternative Medicine, vol. 1, no. 1, pp. 1-4, 2004.

[32] S. Matsuba, "Complementary and alternative approaches to biomedicine," Evidence-Based Complementary and Alternative Medicine, vol. 1, pp. 345-348, 2004.

[33] W. Hu and T. Fu, "Isolation and properties of a novel fibrinolytic enzyme from an earth worm," Zhong Yao Cai, vol. 20, no. 2, pp. 78-81, 1997.

[34] H. Mihara, M. Maruyama, and H. Sumi, "Novel thrombolytic therapy discovered from traditional oriental medicine using the earthworm," The Southeast Asian Journal of Tropical Medicine and Public Health, vol. 23, pp. 131-140, 1992.

[35] E. L. Cooper, T. M. Hrzenjak, and M. Grdiša, "Alternative sources of fibrinolytic, anticoagulative, antimicrobial and anticancer molecules," International Journal of Immunopathology and Pharmacology, vol. 17, no. 3, pp. 237-244, 2004.

[36] S. Wei, P. Zhang, Y. Dang, H. Zhang, and B. Jiang, "Primary study on effect of various components of modified formula radix hedysari on peripheral nerve regeneration," Zhongguo Xiu Fu Chong Jian Wai Ke Za Zhi, vol. 22, no. 9, pp. 10561059, 2008. 
[37] J. B. Davis and P. Stroobant, "Platelet-derived growth factors and fibroblast growth factors are mitogens for rat Schwann cells," Journal of Cell Biology, vol. 110, no. 4, pp. 1353-1360, 1990.

[38] M. R. Feneley, J. W. Fawcett, and R. J. Keynes, "The role of Schwann cells in the regeneration of peripheral nerve axons through muscle basal lamina grafts," Experimental Neurology, vol. 114, no. 3, pp. 275-285, 1991.

[39] H. Y. Zhang and X. C. Tang, "Neuroprotective effects of huperzine A: new therapeutic targets for neurodegenerative disease," Trends in Pharmacological Sciences, vol. 27, no. 12, pp. 619-625, 2006.

[40] C. Huang, K. Jacobson, and M. D. Schaller, "MAP kinases and cell migration," Journal of Cell Science, vol. 117, no. 20, pp. 4619-4628, 2004.

[41] J. Witowsky, A. Abell, N. L. Johnson, G. L. Johnson, and B. D. Cuevas, "MEKK1 is required for inducible urokinasetype plasminogen activator expression," Journal of Biological Chemistry, vol. 278, no. 8, pp. 5941-5946, 2003.

[42] J. Yu, D. Bian, C. Mahanivong, R. K. Cheng, W. Zhou, and S. Huang, "P38 mitogen-activated protein kinase regulation of endothelial cell migration depends on urokinase plasminogen activator expression," Journal of Biological Chemistry, vol. 279, no. 48, pp. 50446-50454, 2004.

[43] M. García-Rocha, J. Avila, and R. Armas-Portela, “Tissue-type plasminogen activator ( $\mathrm{tPA}$ ) is the main plasminogen activator associated with isolated rat nerve growth cones," Neuroscience Letters, vol. 180, no. 2, pp. 123-126, 1994.

[44] R. N. Pittman and A. J. DiBenedetto, "PC12 cells overexpressing tissue plasminogen activator regenerate neurites to a greater extent and migrate faster than control cells in complex extracellular matrix," Journal of Neurochemistry, vol. 64, no. 2, pp. 566-575, 1995.

[45] E. Ulfhammer, P. Larsson, L. Karlsson et al., "TNF- $\alpha$ mediated suppression of tissue type plasminogen activator expression in vascular endothelial cells is NF- $\kappa \mathrm{B}$ - and p38 MAPKdependent," Journal of Thrombosis and Haemostasis, vol. 4, no. 8, pp. 1781-1789, 2006.

[46] S. M. Hayden and N. W. Seeds, "Modulated expression of plasminogen activator system components in cultured cells from dissociated mouse dorsal root ganglia," Journal of Neuroscience, vol. 16, no. 7, pp. 2307-2317, 1996.

[47] P. A. Andreasen, L. Kjøller, L. Christensen, and M. J. Duffy, "The urokinase-type plasminogen activator system in cancer metastasis: a review," International Journal of Cancer, vol. 72, no. 1, pp. 1-22, 1997.

[48] R. Hildenbrand, M. Gandhari, P. Stroebel, A. Marx, H. Allgayer, and N. Arens, "The urokinase-system-role of cell proliferation and apoptosis," Histology and Histopathology, vol. 23, no. 1-3, pp. 227-236, 2008.

[49] K. Dass, A. Ahmad, A. S. Azmi, S. H. Sarkar, and F. H. Sarkar, "Evolving role of uPA/uPAR system in human cancers," Cancer Treatment Reviews, vol. 34, no. 2, pp. 122-136, 2008.

[50] D. Muir, "Metalloproteinase-dependent neurite outgrowth within a synthetic extracellular matrix is induced by nerve growth factor," Experimental Cell Research, vol. 210, no. 2, pp. 243-252, 1994.

[51] E. M. Muir, K. H. Adcock, D. A. Morgenstern et al., "Matrix metalloproteases and their inhibitors are produced by overlapping populations of activated astrocytes," Molecular Brain Research, vol. 100, no. 1-2, pp. 103-117, 2002.

[52] H. Nagase, "Activation mechanisms of matrix metalloproteinases," Biological Chemistry, vol. 378, no. 3-4, pp. 151-160, 1997.
[53] G. H. Ryu, S. Park, D. K. Han, Y. H. Kim, and B. Min, "Antithrombotic activity of a lumbrokinase immobilized polyurethane surface," ASAIO Journal, vol. 39, no. 3, pp. M314-M318, 1993.

[54] H. Mihara, H. Sumi, T. Yoneta et al., "A novel fibrinolytic enzyme extracted from the earthworm, Lumbricus rubellus," Japanese Journal of Physiology, vol. 41, no. 3, pp. 461-472, 1991.

[55] H. Ji, L. Wang, H. Bi et al., "Mechanisms of lumbrokinase in protection of cerebral ischemia," European Journal of Pharmacology, vol. 590, no. 1-3, pp. 281-289, 2008.

[56] H. Chen, S. Takahashi, M. Imamura et al., "Earthworm fibrinolytic enzyme: anti-tumor activity on human hepatoma cells in vitro and in vivo," Chinese Medical Journal, vol. 120, no. 10, pp. 898-904, 2007.

[57] Y. Tang, D. Liang, T. Jiang, J. Zhang, L. Gui, and W. Chang, "Crystal structure of earthworm fibrinolytic enzyme component A: revealing the structural determinants of its dual fibrinolytic activity," Journal of Molecular Biology, vol. 321, no. 1, pp. 57-68, 2002.

[58] J. Zhao, R. Pan, J. He, Y. Liu, D.-F. Li, and R.-Q. He, "Eisenia fetida protease-III-1 functions in both fibrinolysis and fibrogenesis," Journal of Biomedicine and Biotechnology, vol. 2007, Article ID 97654, 2007.

[59] T. Hrženjak, M. Popović, T. Božić, M. Grdisa, D. Kobrehel, and L. Tiška-Rudman, "Fibrinolytic and anticoagulative activities from the earthworm Eisenia foetida," Comparative Biochemistry and Physiology Part B, vol. 119, no. 4, pp. 825-832, 1998.

[60] T. Hrzenjak, M. Hrzenjak, V. Kasuba, P. EfenbergerMarinculic, and S. Levana, "A new source of biologically active compounds-earthworm tissue (Eisenia foetida, Lumbricus rubelus)," Comparative Biochemistry and Physiology Part A, vol. 102, no. 3, pp. 441-447, 1992.

[61] M. Popović, T. M. Hrženjak, T. Babić, J. Kos, and M. Grdiša, "Effect of earthworm (G-90) extracton formation and lysis of clots originated from venous blood of dogs with cardiopathies and with malignant tumors," Pathology and Oncology Research, vol. 7, no. 3, pp. 197-202, 2001.

[62] M. Grdisa, M. Popovic, and T. Hrzenjak, "Glycolipoprotein extract (G-90) from earthworm Eisenia foetida exerts some antioxidative activity," Comparative Biochemistry and Physiology Part A, vol. 128, no. 4, pp. 821-825, 2001.

[63] M. Hrzenjak, D. Kobrehel, S. Levanat, M. Jurin, and T. Hrzenjak, "Mitogenicity of the earthworm's (Eisenia foetida) insulinlike proteins," Comparative Biochemistry and Physiology Part B, vol. 104, no. 4, pp. 723-729, 1993.

[64] M. Popović, T. Hrženjak, M. Grdiša, and S. Vuković, "Adhesins of immunoglobulin-like superfamily from earthworm Eisenia foetida," General Pharmacology, vol. 30, no. 5, pp. 795-800, 1998.

[65] M. Grdiša, M. Popović, and T. Hrženjak, "Stimulation of growth factor synthesis in skin wounds using tissue extract (G-90) from the earthworm Eissenia foetida," Cell Biochemistry and Function, vol. 22, no. 6, pp. 373-378, 2004.

[66] K. Kolkova, V. Novitskaya, N. Pedersen, V. Berezin, and E. Bock, "Neural cell adhesion molecule-stimulated neurite outgrowth depends on activation of protein kinase $\mathrm{C}$ and the Ras-mitogen-activated protein kinase pathway," Journal of Neuroscience, vol. 20, no. 6, pp. 2238-2246, 2000.

[67] S. Diestel, C. L. Hinkle, B. Schmitz, and P. F. Maness, "NCAM140 stimulates integrin-dependent cell migration by ectodomain shedding," Journal of Neurochemistry, vol. 95, no. 6, pp. 1777-1784, 2005. 
[68] J. G. Boyd and T. Gordon, "A dose-dependent facilitation and inhibition of peripheral nerve regeneration by brain-derived neurotrophic factor," European Journal of Neuroscience, vol. 15, no. 4, pp. 613-626, 2002.

[69] A. Hirata, T. Masaki, K. Motoyoshi, and K. Kamakura, "Intrathecal administration of nerve growth factor delays GAP 43 expression and early phase regeneration of adult rat peripheral nerve," Brain Research, vol. 944, no. 1-2, pp. 146156, 2002. 


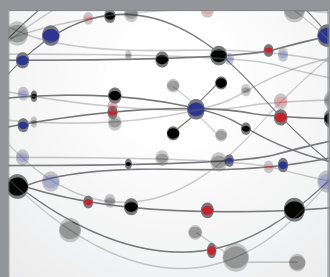

The Scientific World Journal
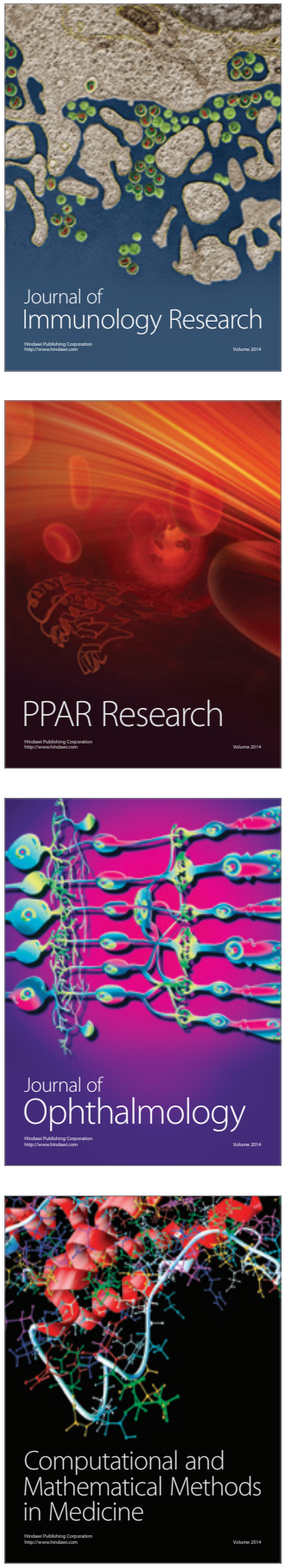

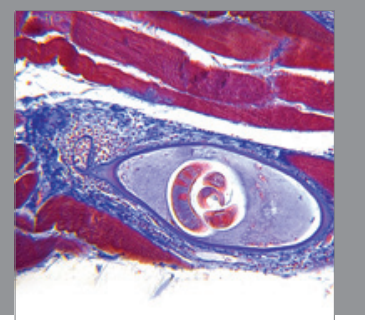

Gastroenterology

Research and Practice
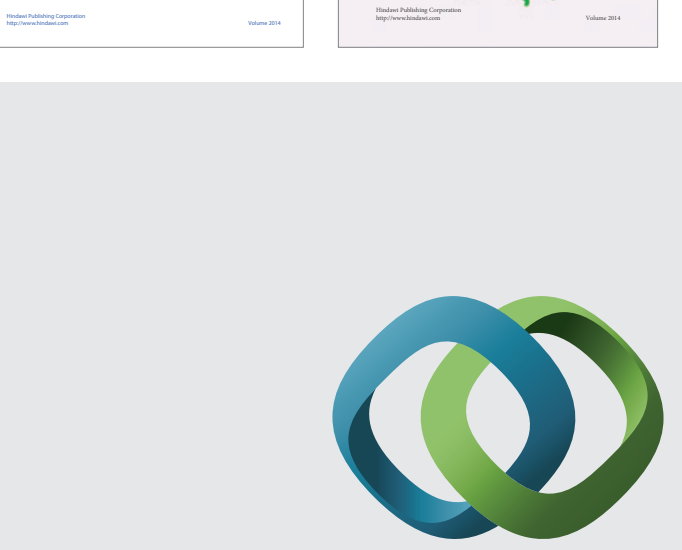

\section{Hindawi}

Submit your manuscripts at

http://www.hindawi.com
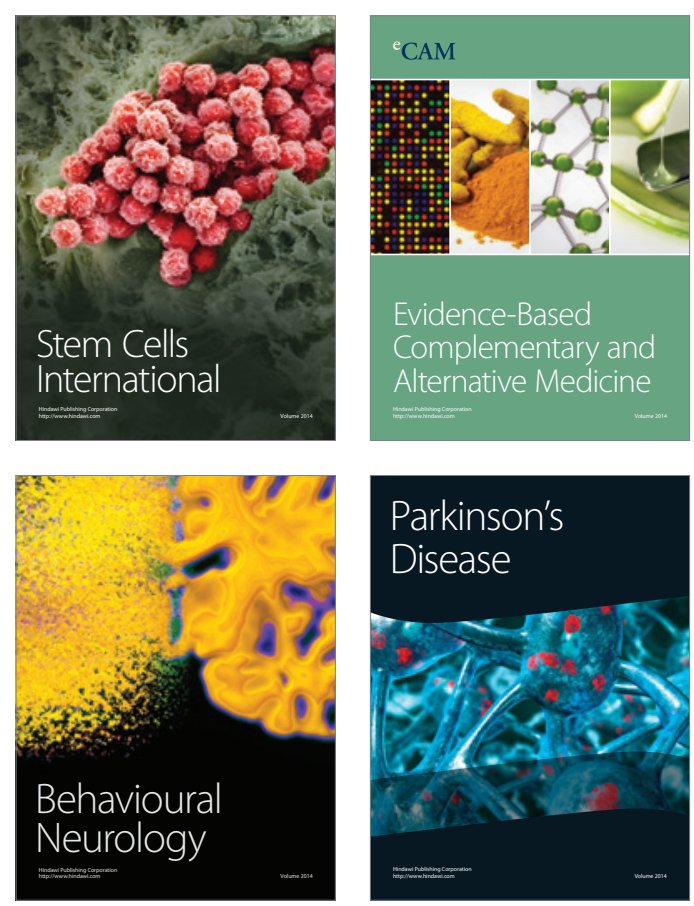

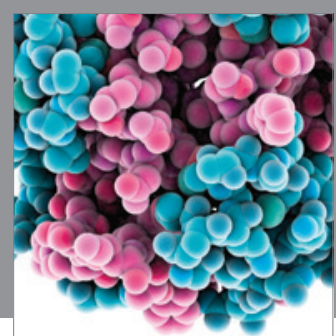

Journal of
Diabetes Research

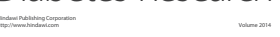

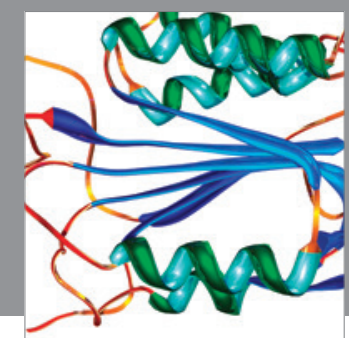

Disease Markers
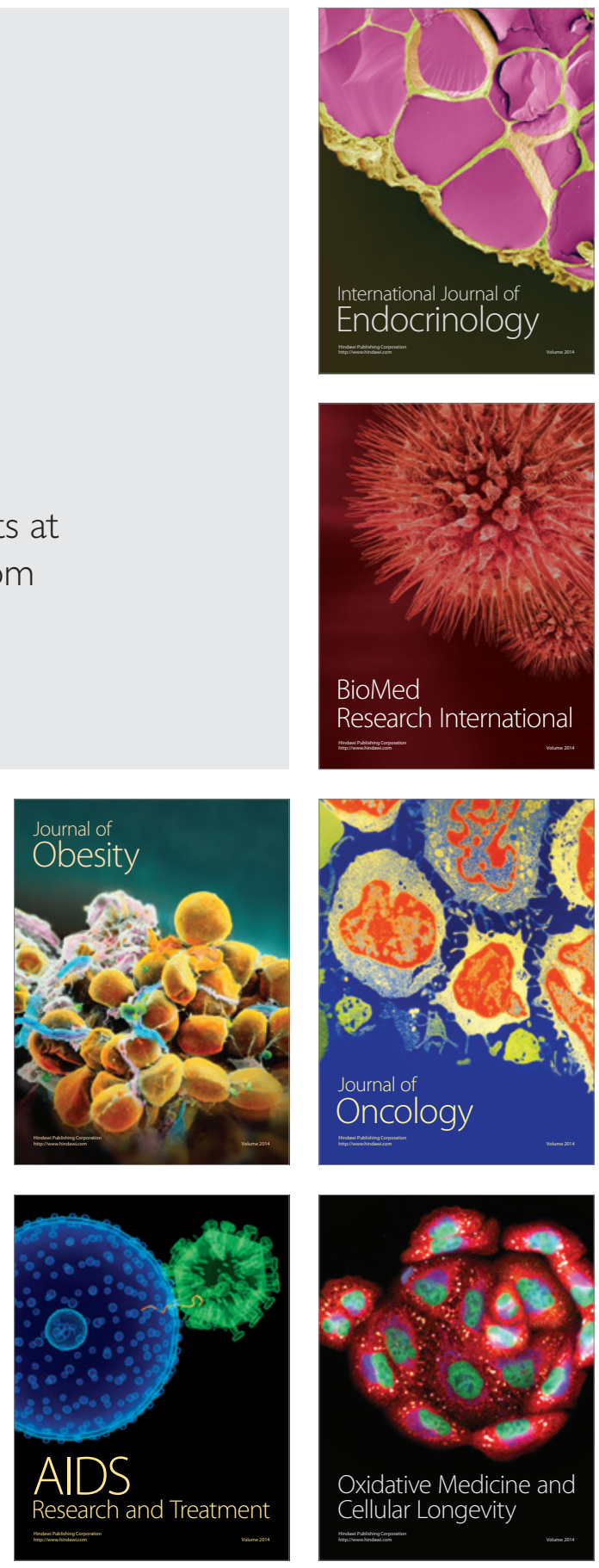